\title{
Deposit Insurance Scheme Activities on Deposit Mobilization of International Association of Deposit Insurer Member Countries: Post Coreprinciple Effect
}

\author{
Amenawo Ikpa Offiong ${ }^{1}$, Peter Kekung Bessong ${ }^{2}$, Arikpo Oka Felix ${ }^{1}$, Godwin Bassey James ${ }^{1} \&$ Anthony Ogar $^{1}$ \\ ${ }^{1}$ Department of Banking and Finance, Faculty of Management Science, University of Calabar, Calabar, Nigeria \\ ${ }^{2}$ Department of Accounting, Faculty of Management Science, University of Calabar, Calabar, Nigeria \\ Correspondence: Amenawo Ikpa Offiong (Ph.D), Department of Banking and Finance, University of Calabar, \\ Calabar, Nigeria.
}

Received: July 8, 2020

doi:10.5430/ijfr.v11n6p73
Accepted: September 9, 2020

Online Published: November 30, 2020

URL: https://doi.org/10.5430/ijfr.v11n6p73

\begin{abstract}
This study examined deposit insurance schemes' activities and its effect on deposit mobilization of the International Association of Deposit Insurers (IADI) member countries. The study dwelled on the banking sectors post-core principles of the member countries. The study assessed the effect of deposit insurance fund, deposit insurance cover, deposit insurance premium and deposit fully covered on the total deposit of the banking sectors of 21 member countries of IADI spanning the period 2014 to 2018. Data were sourced from the annual reports of the selected countries Deposit Insurance Agencies. The study adopted the ex-post facto research design. The estimating technique was panel Vector Error Correction Model (VECM). Findings from the analyses showed that deposit insurance scheme activities of member countries did not significantly affect IADI's member countries banking sectors deposit mobilization after the implementation of the core principle. IADI, as a policy-making body must, therefore, review and localize its core principles and policies in line with member countries' uniqueness and financial realities through investment in research in member countries to isolate unique factors peculiar to member countries and streamline policies to capture member countries' financial and economic conditions. IADI should monitor the compliance level of member countries to ensure strict implementation of its policy and principles by member countries.
\end{abstract}

Keywords: deposit insurance fund, deposit insurance cover, deposit insurance premium, deposit fully covered, IADI, deposit mobilization

\section{Introduction}

In any economy of the world, the banking sector is regarded as the vehicle that brings about the desired economic growth and development, as such; it becomes imperative for governments of various nations to deliberately set in motion a banking system that is considered efficient. Such banking system would not only be for the enhancement of efficient intermediation but would strife to facilitate depositors' funds' security and protection, promote efficient and healthy competition among banks, maintain and sustain confidence in the banking public, maintain the banking system stability and protection against systemic and operational risk and collapse. Globally, the banking system is regarded as the most regulated sector of the economy because of its pivotal position in the economic system (Akogun, 2010).

Banks mobilize deposits from the surplus economic units with a promise to compensate the depositors for parting with their funds and the understanding that the deposits funds are safe and secured with banks. These deposits form the bases upon which loans and advances are extended to the deficit economic units and other investment vehicles are funded. In doing these, banks earn margins above the cost of mobilizing deposits, the higher the earnings from banks' lending and investments, the higher the margin that the banks secure. Seeking to maximize bank earnings, banks' managements are motivated to embark on sub-optimal investments and lending decisions, such as lending to high-risk individuals and funding highly risky investment; a situation which could lead to loss of depositors' funds, loss of confidence in the banking sector and even slow down the economic progress of any economy. This is why banks are the most regulated of all sectors globally. One aspect of bank regimentation is the deposit insurances scheme; a system that promises to compensate deposits for their funds in the event where an insured bank is unable 
to meet up with its obligation to its depositors.

Before the 2008 global financial crises, the need for countries to strengthen the deposit insurance element of the safety net of the financial sector was handled dreamily. However, with the debilitating effects of the 2008 global financial crises and the core principles of effective deposit insurance issued jointly by the International Association of Deposit Insurers (IADI) and the Basel Committee for Banking Supervision in 2009, there has been an increased demand for deposits insurance schemes globally. This has led many countries of the world into introducing explicit deposit insurance schemes or extending the coverage and scope, of existing schemes. Thus, deposit insurance schemes of various economies have been strengthened to perform the core responsibilities of restoring stability to the banking system through the prevention of runs on illiquid but solvent banks and the payments of claims to insured deposits (Beat \& Susanna, 2009).

The post-global financial crisis-era witnessed drastic regimentation of deposit insurance operations globally. For instance, the European Union introduced a new directive on deposit guarantee scheme known as Maximum Harmonization Directive (MHD). This directive created a minimum target for deposit insurance fund, established risk-based premium investment rules for deposit insurance fund and spelt out the requirements for stress testing (Jan \& Isfandyar, 2017). Similarly, with the review of the core principles of IADI, almost all the G20 member countries have in place deposit insurance schemes. For instance, China and Saudi Arabia introduced the scheme in 2015 while South Africa had proposed its introduction in the nearest future. The critical concern bothered on whether or not deposit insurance practices by IADI member countries, especially after the adoption of the core principles have been effective enough to adequately protect depositors' funds, restore the stability of the banking sector and boost the confidence imposed on banking sectors of these member countries especially during periods of economic and financial crises. A careful review of reported deposits mobilized by insured banks within IADI member countries suggests that deposit insurance activities after the implementation of the core principle are yet to achieve its full gains. For instance, in Nigeria, the total deposit of insured banks from 7.45 per cent in 2014, increased to 74.2 per cent in 2015 but decreased to 12.77 per cent and 4.18 per cent in 2016 and 2018 respectively. Similarly, the total deposit of insured banks as reported by the Federal Deposit Insurance Corporation from 5.96 per cent, decreased to 5.21 per cent, 3.73 per cent and 1.97 per cent in 2015, 2017 and 2018 respectively. Again, the total deposit of insured banks as published by the Australian Prudential Regulation Authority showed that from 11.62 per cent in 2014, the deposit by insured banks decreased to 9.32 per cent, 6.67 per cent 5.93 per cent and 5.26 per cent in 2015, 2016, 2017 and 2018 respectively.

Given the above reports on the deposit mobilization capacity of insured banks within IADI member countries, it seems the implementation of the core principle by these countries is yet to build confidence in the banking sector of these countries and consequently enhance deposit mobilization capacity. The limitation of this study is that some IADI member countries and agency lacked explicit data on deposit insurance activities. The study therefore concentrated effort on countries with data for the variables and time covered by this study. The study is significant because it enables us access post-implementation of the core principle by member countries of IADI. This study, therefore, departs from all available studies in that it is the first to assess the post-core principle effect of deposit insurance scheme on deposit mobilization of IADI member countries. In doing this, deposit insurance scheme activities were measured in terms of the deposit insurance fund, insurance premium, deposit insurance cover and the deposit fully covered against banks' deposits of IADI member countries between the periods of 2015 to 2018 .

\section{Literature Review}

The anchor theory for this study is the economic theory of deposit liability insurance propounded by Diamond and Dybvig (1983). According to this theory, banks mobilize funds for investment in productive activities which promise high payoffs when allowed till maturity. The sources of funds used by banks to finance these investments are depositors' funds. Depositors' funds are however requested at short notice and must be honoured by the bank to avoid banks run. Banks on the other hand invest these funds on demandable debts to meet up with deposits option. Excessive withdrawals of depositors' funds may result in the premature termination of bank investment and its resultant lower payoffs. This would reduce the return on investment of banks and create liquidity risk as banks would be unable to meet up with all withdrawals occasioned by the bad Nash equilibrium created by depositors seeking to withdraw because they expect all other depositors to run to the bank for withdrawals. Deposit insurance scheme is therefore an attempt according to Diamond and Dybvig (1983) to, without any cost, eliminate banks' liquidity risk by making depositors payoffs independent of other depositors' drawings.

In light of this, deposit insurance mostly works as a stabilization device. If depositors are assured that their funds would be paid back using funds from the insurance pool despite the expectations from other depositors, then they are 
no longer afraid to hurriedly withdraw their funds. Deposit insurance thus helps maintain equilibrium and reduces the need for panic withdrawal. The economic cost of insurance is therefore zero (Anginer \& Demirguc-Kunt, 2018). The reliability of the insurance of depositors' fund in the Diamond-Dybvig model lies mainly on the belief that the coverage is seen to be fair and secured by fund savers themselves. If fund savers believe that the insurer is compromised and will not have sufficient money, then it becomes necessary for the investors to rush and withdraw their deposits. Scholars all over the world have at various times examined deposit insurance effect on depositors, lending and the soundness and confidence imposed on the banking sector, for instance, Piotr, Chun and Klaus (2019) examined the role of private deposit insurance for deposit flows and bank lending during the financial crisis. The study employed descriptive statistics and comparative analyses of private deposit insurance and federal deposit insurance in Massachusetts. The study found that the private sector played a complementary role for the regulatory framework in the banking sector. The study further found banks whose deposits were insured privately had greater deposit flows and larger credit extension than banks whose deposits were guaranteed by the Federal deposit insurance. The adoption of a descriptive approach called for a more detailed empirical analysis of the subject to establish a cause-effect relationship between insurance and deposit flow. This is what the current study is meant to achieve.

Pham and Dao (2020) did an exploratory study of the deposit insurance scheme; its type, benefits, and cost. To achieve the study's objectives literature was reviewed on the different types of the scheme adopted by countries, the benefits and costs of adoption in promoting stability in the banking sector. The study found from the reviewed literature that countries have shown greater commitment to establishing a deposit insurance scheme. Based on these findings, the study recommended that effort must be made in the design of a deposit insurance scheme to ensure that their benefits are not outweighed by the cost of implementation. The study however failed to conduct an empirical analysis but rather resorted to an exploratory survey of the literature. The study, however, differed from this study by conducting an empirical analysis of deposit insurance scheme on deposit mobilization to guarantee a robust analysis and better conclusion. Andreas, Larysa and Sergii (2018) undertook a comparative analysis of deposit insurance systems of post-Soviet countries in 2017. The study sampled 15 post-Soviet countries and based the comparison on its adoption and regulatory coverage within the period 2017. Findings from the analyses showed that post-Soviet countries are on their way to developing insurance systems to efficiently protect depositors. The study blames the partial acceptance of the EU deposit insurance regulation on the divergent costs of economic development of the post-Soviet countries. The comparative nature of this study necessitated a new study to examine the effect of deposit insurance scheme on depositors' funds. This was the gap this study sought to bridge.

Sebastine (2009) studied financial turbulence and some lessons regarding deposit insurance. The study reviewed issues surrounding deposit insurance and provided an overview of some key challenges relating to the design of explicit deposit insurance systems. The study found that the challenges associated with the design of an explicit deposit insurance system include its coverage, funding, premium setting, membership, safety net interactions, and bank failure resolution mechanisms. The study also found that deposit insurers have extensive failure resolution powers in some countries than in others. The concentration by this author on the failure resolution of deposit insurance scheme created a window for the assessment of whether deposit insurance in the first place promotes confidence among deposits as evidence by their deposit mobilization capacity which was the focus of this current study. Falko, Stefan and Patrick (2019) examined fear, deposit insurance schemes, and deposit reallocation in the Germany banking system. The study obtained data on depositors' fear of bank failure, outstanding overnight deposit, and monetary institution interest rate. The study applied descriptive statistics, univariate analyses, and Vector Autoregressive test. The study further applied the Granger causality test and panel analysis for the period from June 2005 to June 2016. Findings from the analyses revealed both for the state and bank-level data explicit deposit insurance scheme enhances the confidence of depositors in the banking sector in Germany. While these authors incorporated monetary institution interest rate into their model in arriving at their conclusion, the current study has eliminated interest rate and incorporates such variables as deposit insurance fund, deposit insurance cover; deposit insurance premium and deposit fully cover as measures of the deposit insurance scheme. This clearly provides a basis for an effective examination of the subject for a better conclusion.

Honohan and Klingebiel (2000) studied the impact of banks' deposit insurance guarantee and other crisis management strategies on the ultimate fiscal cost of resolving distress in the banking sector. Financial crises data were collected over 40 years period and analyzed. The study found based on the analyses that unlimited deposit guarantees, open-ended liquidity support, and regulatory forbearance had a significant positive effect on the ultimate fiscal cost of resolving the banking crisis. The study also found that there was no trade-off between fiscal costs and the speed of economic recovery. The study also found that depositors' guarantees and regulatory forbearance failed to 
significantly decrease either crisis duration or the crisis induce a decline in aggregate real output. The examination of deposit insurance guarantee against economic recovery rather than deposit mobilization created a gap that leads to this study examining deposit insurance scheme on deposit mobilization. Demirguc-Kunt and Edward (2002) investigated where in the globe deposit insurance work. The study reviewed various literature cutting across countries that had implemented an explicit guarantee scheme, deposit insurance design, how deposit insurance affects market discipline, how deposit insurance affects financial development and how explicit deposit insurance affects bank stability. The study found that it is difficult to design deposit insurance that will increase the depth and probability of future banking crises. It was also shown that deposit insurance can help to develop a resilient financial system only in economies with contracting environments permitting reliable institutions to control losses. The current study deviates from this study by taking a completely different methodological technique. While the authors only adopted an exploratory approach in arriving at their conclusions, this current study adopted an empirical technique using the panel VECM technique.

Anginer and Demirguc-Kunt, (2018) examined a deposit insurance review of bank runs and moral hazard. The study reviewed the economic costs and benefits of deposit insurance, highlighting the importance of institutions and specific design features for deposit insurance schemes work. The study found that laws and specific features of a country's private and public environments enhance deposit insurance design and adoption. While the authors limited their study to an exploratory assessment of deposit insurance review of bank runs on moral hazard, this current study is a thorough empirical examination of the deposit insurance scheme on deposit mobilization. Olukotun, James and Olorunfemi (2013) assessed bank distress in Nigeria and the Nigeria Deposit Insurance Corporation intervention. Data were gotten via the secondary source. The coefficient of correlation and the r-test were employed to determine the relationship between the variables. The result of the findings showed that as a result of the increase in deposit guarantee, there is also an increase in the mobilization of deposits. Furthermore, the study found that NDIC has moved from the flat-rate premium system of assessment to a different premium system of assessment. The researchers recommended that deposit cover should be appraised regularly to the dictates of the economy. The scope of this study is narrowed to NDIC in Nigeria. However, the scope of the current study is IADI agencies in the whole world. Girma and Jique (2018) studied how deposit mobilization impacts on the financial sustainability of rural cooperatives credits and savings in Ethiopia covering 2014-2016. The study applied the panel regression model to estimate parameters of deposit mobilization such as demand deposit ratio, the volume of deposits, deposit to assets ratio, and deposit to loan ratio against financial sustainability. The panel regression results of the study discovered that the deposits mobilization parameters significantly impact financial sustainability, however, interest rate spread inversely relates to financial sustainability. The study is an assessment of deposit mobilization on financial stability in Ethiopia; the current study is deposit insurance scheme on deposit mobilization in IADI affiliated deposit insurance agencies in the world

Ani and Ogar (2018) observed the impact of deposit insurance funds partially covered on the safety of bank deposits in Nigeria. The work used data from the NDIC annual reports and banking supervisory and stability reports. The study adopted the ex-post factor, and exploratory designs and used ordinary least squared technique to estimate the relevant equation of the study. The result of the analysis of the study revealed a significant positive impact of deposit insurance funds on bank deposits in Nigeria. Amongst the recommendation of the study was that Nigeria deposit insurance corporations have to monitor the full coverage levels in compliance with international best practices in association with an increased market drive for low-value account customers to improve the total deposit partially covered. The geographical scope of this study was Nigeria. However, the geographical scope of the current study was IADI's deposit insurance agencies in all countries of the world. Karabulut and Bilgin (2007) used the ordinary least square (OLS) to estimate the linkage between deposit insurance and deposit mobilization. Using monthly data derived from the Turkish Central Bank, they provide empirical evidence that deposit insurance had significantly influenced deposit mobilization in the Turkish financial sector. It was also revealed that there existed an increase in the volume of non-performing loans as deposit insurance was adopted in Turkey. The study applied the ordinary least squared multiple regression and the data analysis technique and the study only limited its scope to thr Turkish Central Bank. This current study however concentrates on all IADI deposit insurance agencies in the world, using the VECM panel approach as the analytical basis.

Peia and Vranceanu (2017) investigated bank runs under partial deposit insurance. The study applied the error correction mechanism and found evidence that the best partial deposit insurance reduces bank runs. The study also found that increasing deposits to assets ratio mean growing the available funds for bank use in various profitable and productive activities such as lending and investments. The authors only considered implicit insurance schemes and measured it against deposit to asset ratio proxy for bank runs. This study deviates and considered explicit insurance 
measured in terms of the deposit insurance fund, deposit insurance cover, deposit fully covered, and deposit insurance premium. Ngalawa, Tchana and Viegi, (2016) used canonical correlation analysis and panel least square method to measure the relationship between banking uncertainty and deposit insurance, using the function of moral hazard. The study found that deposit insurance was the most important factor that influences the financial sector stability. The studies further showed that bank costs and the composition of bank credit significantly determine the level of financial stability in the financial subsector. The asset part of the financial sector was used to measure financial stability without considering the liability portion effect of deposit insurance on the financial sector. This study therefore is a balance of Ngalawa, Tchana and Viegi (2016) as it examined deposit insurance effect on the deposit liability component of the financial sector.

Ebiaghan (2019) studied the interconnection between the hypothesis of moral hazard and deposit insurance scheme (DIS) adoption and implementation in Nigeria. By employing a multiple regression model (Generalized Method of Moments (GMM), the study revealed that deposit insurance funds and the indicators of assets quality in banks in Nigeria had a positive and significant relationship following the moral hazard hypothesis. From the study's point of view, there is a need for that government to strengthen its banking regulatory systems which would reduce the unwanted risk. The study concentrated only on deposit insurance on asset quality. The study did not take notice of the liability aspect or quality of the Nigerian banks. This study is therefore an attempt to bridge this gap by considering how deposit insurance schemes influence the deposit mobilization potential of deposit money banks in IADI's countries. Enkhbold and Otgonshar (2013) conducted a study on deposit insurance and risk-taking in Asian banks. The risk taken was peroxide by the cost of holding deposit reserves while deposit insurance was measured. The study sorts out the role of reducing the opportunity costs of holding deposit reserves through the deposit insurance system. The study adopted the panel least square technique, and the results of the study suggested that deposit insurance had a positive and significant influence on the risk-taking of banks in Asian. The study narrowed its scope to only Asian countries. However, this study extents to all IADI's agencies in the world at large, using the VECM panel approach as the analytical basis from 2015 to 2018 .

\section{Method}

This research adopted the ex-post facto design, which was applied to collect data of secondary nature on the study's variables. Annual time series data were collected for 21 member countries of IADI for the period 2014 to 2018. The judgemental sampling technique was adopted in selected 21 IADI member countries out of 87, excluding associate members and partners based on data availability. The functional linkage between the series of this study was expressed thus:

$$
\text { TDEP }=\text { F (DIF, DIC, DIP, DFC) }
$$

The application of the panel unit root test summary showed that all the series were of order I(1), hence, the study estimated the relationship among the variables using the Panel VECM test. The study also applied the Pedroni residual cointegration test for the long-run association of the variables. Being a restricted VAR model, the VEC model contains a cointegration association with huge fluctuation in the short-term dynamic, VEC expressions can restrict the long-term trend of the endogenous series and be convergent to their cointegration relation. Having the assumption that $\mathrm{y}_{\mathrm{t}}=\left(\mathrm{y}_{1 \mathrm{t}}, \ldots \ldots \ldots, \mathrm{y}_{\mathrm{kt}}\right)^{\prime}$ given a stochastic time series $\mathrm{k}$-dimensional, $\mathrm{t}=1,2, \ldots \ldots \ldots, \mathrm{T}$ and $\mathrm{y}_{\mathrm{t}} \sim \mathrm{I}(1)$, each $\mathrm{y}_{\mathrm{it}} \sim \mathrm{I}(1), \mathrm{i}=1,2, \ldots \ldots \ldots \ldots, \mathrm{k}$ is influenced by exogenous time series of d-dimension $\mathrm{x}_{\mathrm{t}}=\left(\mathrm{x}_{1 \mathrm{t}}, \mathrm{x}_{2 \mathrm{t}}, \ldots \ldots \ldots, \mathrm{x}_{\mathrm{dt}}\right)^{\prime}$; therefore specifying the VAR as:

$$
\begin{aligned}
& \mathrm{Y}_{\mathrm{t}}=\mathrm{A}_{1} \mathrm{y}_{\mathrm{t}-1}+\mathrm{A}_{2} \mathrm{y}_{\mathrm{t}-2}+\ldots \ldots \ldots \ldots+\mathrm{A}_{\mathrm{p}} \mathrm{y}_{\mathrm{t}-\mathrm{p}}+\mathrm{Bx}_{\mathrm{t}}+\mathrm{ut} \\
& \mathrm{t}=1,2, \ldots \ldots \ldots, \mathrm{T}
\end{aligned}
$$

If $\mathrm{y}_{\mathrm{t}}$ could not be influenced by the $\mathrm{d}$-dimension of the exogenous time series $\mathrm{x}_{\mathrm{t}}=\left(\mathrm{x}_{1 \mathrm{t}}, \mathrm{x}_{2 \mathrm{t}}, \ldots \ldots \ldots, \mathrm{x}_{\mathrm{dt}}\right)^{\prime}$, therefore, the equation (2) can be re-specified as:

$$
\begin{aligned}
& \mathrm{Y}_{\mathrm{t}}=\mathrm{A}_{1} \mathrm{y}_{\mathrm{t}-1}+\mathrm{A}_{2} \mathrm{y}_{\mathrm{t}-2}+\ldots \ldots \ldots+\mathrm{A}_{\mathrm{p}} \mathrm{y}_{\mathrm{t}-\mathrm{p}}+\mathrm{u}_{\mathrm{t}} \\
& \mathrm{t}=1,2, \ldots, \mathrm{T}
\end{aligned}
$$

Transforming equation (3), the VAR model can be specified as:

$$
\Delta y_{t}=\prod y_{t-1}+\sum_{i=1}^{p-1} \Gamma_{i} \Delta y_{t-1}+\mu_{t}
$$


Where,

$$
\begin{gathered}
\Pi=\sum_{i-1}^{p} A_{i}-1 \\
\Gamma_{i}=-\sum_{j-i+1}^{p} A_{j}
\end{gathered}
$$

If the relationship in $\mathrm{y}_{\mathrm{t}}$ is cointegrated, therefore, $\prod \mathrm{y}_{\mathrm{t}-1} \sim \mathrm{I}(0)$ and equation (4) will now become:

$$
\Delta y_{t}=\alpha \beta^{\prime} y_{t-1}+\sum_{i=1}^{p-1} \Gamma_{i} \Delta y_{t-1}+\mu_{t}
$$

where $\beta^{\prime} \mathrm{y}_{\mathrm{t}-1}=\mathrm{ecm}_{\mathrm{t}-1}$ is the error correction term, which reflects long-term equilibrium relationships between series and can be re-specified as:

$$
\Delta y_{t}=\alpha e c m_{t-1}+\sum_{i=1}^{p-1} \Gamma_{i} \Delta y_{t-1}+\mu_{t}
$$

Lastly, equation (6) represents VECM with error correction model in each of the cointegration equation. Thus, the functional VECM equation in this study is specified as:

$$
\begin{aligned}
\Delta I n T D E P_{t}= & \sum_{I=1}^{P=1} \rho_{I} \Delta \operatorname{InTDE} P_{t-1}+\sum_{I=1}^{P=1} \rho_{2} \Delta \operatorname{InDIF} F_{t-1}+\sum_{I=1}^{P=1} \rho_{3} \Delta I n D I C_{t-1}+\sum_{I=1}^{P=1} \rho_{4} \Delta \operatorname{InDI} P_{t-1}+ \\
& \sum_{I=1}^{P=1} \rho_{5} \Delta \operatorname{InDFC} C_{t-1}+Z 1^{*} E C M 1_{t-1}+e_{1 t}
\end{aligned}
$$

Where:

TDEP- Bank Deposit; DIF-Deposit Insurance Fund; DIC- Deposit insurance Covered; DIP-Deposit Insurance Premium; DFC- Deposit Fully Covered;

$\rho_{1}-\rho_{4}=$ Short Run Coefficient; $\mathrm{e}_{1 \mathrm{t}}=$ equation residual and ECM1 $1_{\mathrm{t}-1}=$ Lagged residual value of the cointegration regression of the model.

Negative and significant of error correction model coefficient implies that there exists a long-run causality from DIF, DIC, DIP, and DFC to the dependent variable, TDEP.

\section{Results and Discussions}

The result in Table 1 was the descriptive statistics of the unlogged data. The data was transformed to enhance a clearer appraisal of the properties of the data set. Accordingly, the result showed that total banks' deposit (TDEP) had an average value of 494.34 with a standard deviation of 262.83 ranging from 17.51 to 980 as the minimum and maximum values. The deposit insurance funds (DIF) had its mean value as 401.53 , a standard deviation of 259.46 with a range from 100.10 and 978.60. Deposit insurance cover showed its minimum value as 10.0 and a maximum of 3000 , with a mean value and standard deviation of 426.71 and 665.74 respectively. The analysis further revealed that the total deposit insurance premium (DIP) had its lowest of 105.61 and the highest of 1736.54. Its average value was 426.19 while its standard deviation was 289.84. Lastly, deposit fully covered (TDPC) had a mean value of 487.79 with a standard deviation of 264.36 ranging from 102.41 to 1968.60 as the minimum and maximum values.

The skewness of the data set showed that all the variables were positively skewed (rightward skewed distribution), meaning that the distribution had a longer right tail than normal. The coefficient of the kurtosis of the total deposits and deposit insurance fund was below 3.0 required for normality. This means that the data set was platykurtic relative to normal. On the other hand, the kurtosis values of deposit insurance cover, deposit insurance premium, and deposit fully covered were greater than 3.0 required for normal, indicating that the data set was leptokurtic relative to normal. The Jarque-Bera (JB) test measured the difference of the skewness and kurtosis values of the series with those of the normal distribution. The JB values of 7.68, 12.51, 464.05, 167.61 and 327.50 for total deposit, deposit insurance fund, deposit insurance cover, deposit insurance premium, deposit fully covered respectively and their corresponding probability, less than 5 per cent confirmed that the dataset was not normally distributed. This actually suggests the transformation of the dataset used for this study. This study, therefore, transformed all the variables using a natural $\log$. 
Table 1. Result of descriptive statistical analysis

\begin{tabular}{llllll}
\hline & TDEP & DIF & DIC & DIP & DFC \\
\hline Mean & 494.3415 & 401.5327 & 426.7157 & 426.1969 & 487.7951 \\
\hline Median & 490.6450 & 340.4600 & 250.0000 & 397.5900 & 456.5650 \\
\hline Maximum & 980.0000 & 978.6000 & 3000.000 & 1736.540 & 1968.600 \\
\hline Minimum & 17.51000 & 100.1000 & 10.00000 & 105.6140 & 102.4100 \\
\hline Std. Dev. & 262.8349 & 259.4685 & 665.7485 & 289.8438 & 264.3691 \\
\hline Skewness & 0.055353 & 0.831779 & 3.016691 & 1.821910 & 1.815400 \\
\hline Kurtosis & 1.660174 & 2.580297 & 11.53156 & 8.114921 & 10.99239 \\
\hline Jarque-Bera & 7.681400 & 12.51019 & 464.0543 & 167.6193 & 327.5094 \\
\hline Probability & 0.021479 & 0.001921 & 0.000000 & 0.000000 & 0.000000 \\
\hline Sum & 50422.83 & 40956.34 & 43525.00 & 43472.08 & 49755.10 \\
\hline Sum Sq. Dev. & 6977302. & 6799713. & 44765325 & 8484953. & 7058994. \\
\hline Observations & 102 & 102 & 102 & 102 & 102 \\
\hline
\end{tabular}

Table 2 presented the correlation matrix result of the study variables, from the result; the correlation coefficient of the relationship between total deposit, deposit insurance fund, and deposit insurance premium of -0.119 and -0.091 with their respective probability values of 23.32 per cent and 36.13 per cent implied negative and insignificant relationship between total deposit, deposit insurance fund and deposit insurance premium in IADI's member countries. The correlation coefficient of total deposit and deposit fully covered of 0.229 with its corresponding probability value of 2.05 per cent however, showed a positive relationship and significant relationship between total deposit and deposit fully covered in IADI's member countries. Again, the correlation coefficient of the relationship between total deposit and deposit insurance cover of -0.225 with its corresponding probability value of 2.26 per cent implied a negative but significant relationship between total deposit and deposit insurance cover in IADI's member countries.

The correlation coefficient of deposit insurance cover, deposit fully covered, and deposit insurance fund of -0.0916 and 0.0795 with their corresponding probability values of 35.94 per cent and 42.68 per cent respectively showed a negative and insignificant relationship between deposit insurance cover, deposit fully covered, and deposit insurance fund in IADI's member countries. However, the correlation coefficient value of the deposit insurance premium, and deposit insurance fund of 0.0074 with its corresponding probability value of 94.05 per cent implied a positive but insignificant relationship of deposit insurance premium and deposit insurance fund in IADI's member countries. Furthermore, the correlation coefficient of deposit insurance premium, deposit fully covered and deposit insurance cover of 0.1212 and 0.0374 with their corresponding probability values of 22.47 per cent and 70.85 per cent respectively showed a positive but insignificant relationship between deposit insurance premiums, deposit fully covered and deposit insurance cover in IADI's member countries. Lastly, the correlation coefficient of deposit fully covered and deposit insurance premium of 0.1081 and its corresponding probability value of 27.95 per cent implied a positive and insignificant relationship.

Table 2. Covariance analysis

\begin{tabular}{llllll}
\hline Correlation & & & & \\
\hline Probability & & & & & \\
\hline Observations & LTDEP & LDIF & LDIC & LDIP & LDFC \\
\hline LTDEP & 1.000000 & & & & \\
\hline & ---- & & & \\
\hline & 102 & & & \\
\hline
\end{tabular}




\begin{tabular}{|c|c|c|c|c|c|}
\hline$\overline{\mathrm{LDIF}}$ & -0.119095 & 1.000000 & & & \\
\hline & 0.2332 & ----- & & & \\
\hline & 102 & 102 & & & \\
\hline \multirow[t]{3}{*}{ LDIC } & -0.225586 & -0.091687 & 1.000000 & & \\
\hline & 0.0226 & 0.3594 & ----- & & \\
\hline & 102 & 102 & 102 & & \\
\hline \multirow[t]{3}{*}{$\overline{\mathrm{LDIP}}$} & -0.091328 & 0.007480 & 0.121271 & 1.000000 & \\
\hline & 0.3613 & 0.9405 & 0.2247 & ----- & \\
\hline & 102 & 102 & 102 & 102 & \\
\hline \multirow[t]{3}{*}{$\overline{\mathrm{LDFC}}$} & 0.229163 & -0.079537 & 0.037474 & 0.108103 & 1.000000 \\
\hline & 0.0205 & 0.4268 & 0.7085 & 0.2795 & ---- \\
\hline & 102 & 102 & 102 & 102 & 102 \\
\hline
\end{tabular}

Table 3 showed that at level, the majority of the methods for all the variables were not statistically significant, meaning that their null hypotheses were accepted. This implied that at levels the data for all the variables had unit root and were not stationary. However, after differencing one time, the majority of the variables become stationery, meaning that their null hypotheses were rejected. This was so as the probability of the respective methods at level was greater than 5 per cent except for the Levin, Lin \& Chu t* method with P-values less than 5 per cent for TDEP, DIF, DIP and DFC respectively. However, after differencing one time the probability of all the methods statistics at became less than 5 per cent except for ADF - Fisher Chi-square with a p-value greater than 5 per cent.

Table 3. Panel unit root test: Summary result

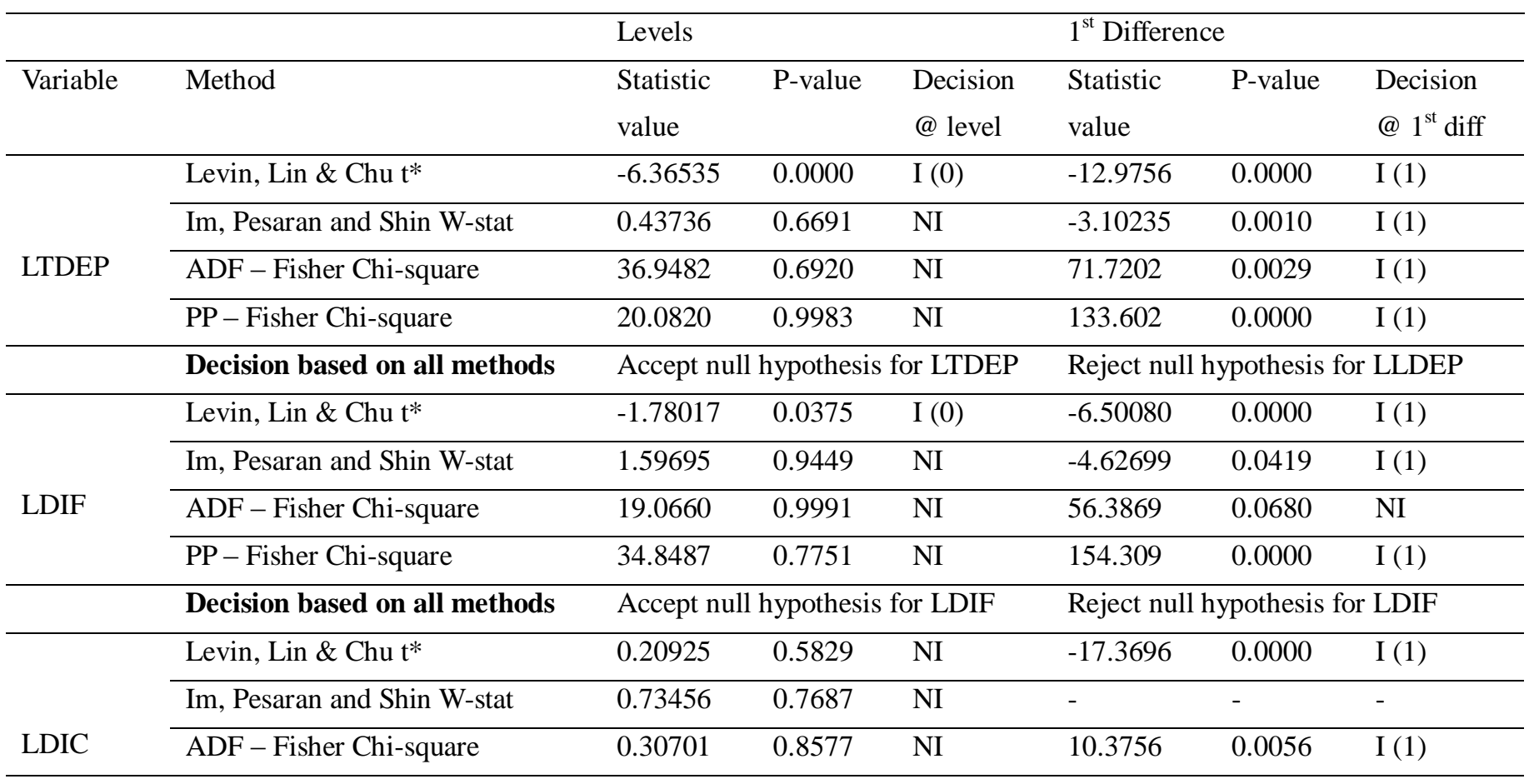




\begin{tabular}{|c|c|c|c|c|c|c|c|}
\hline & $\mathrm{PP}$ - Fisher Chi-square & 0.04748 & 0.9765 & NI & 10.3756 & 0.0056 & I (1) \\
\hline & Decision based on all methods & \multicolumn{3}{|c|}{ Accept null hypothesis for LDIC } & \multicolumn{3}{|c|}{ Reject null hypothesis for LDIC } \\
\hline \multirow{4}{*}{ LDIP } & Levin, Lin \& Chu t* & -2.39897 & 0.0082 & $\mathrm{I}(0)$ & -13.5631 & 0.0000 & I (1) \\
\hline & Im, Pesaran and Shin W-stat & 0.21859 & 0.5865 & NI & -6.08742 & 0.0000 & I (1) \\
\hline & ADF - Fisher Chi-square & 37.1312 & 0.6843 & NI & 120.650 & 0.0000 & I (1) \\
\hline & PP - Fisher Chi-square & 37.8056 & 0.6556 & NI & 146.188 & 0.0000 & $\mathrm{I}(1)$ \\
\hline & Decision based on all methods & \multicolumn{3}{|c|}{ Accept null hypothesis for LDIP } & \multicolumn{3}{|c|}{ Reject null hypothesis for LDIP } \\
\hline \multirow{4}{*}{ LDFC } & Levin, Lin \& Chu t* & -2.74460 & 0.0030 & $\mathrm{I}(0)$ & -14.3794 & 0.0000 & $\mathrm{I}(1)$ \\
\hline & Im, Pesaran and Shin W-stat & 1.30526 & 0.9041 & NI & -6.08791 & 0.0000 & $\mathrm{I}(1)$ \\
\hline & ADF - Fisher Chi-square & 25.5005 & 0.9791 & NI & 119.269 & 0.0000 & I (1) \\
\hline & $\mathrm{PP}$ - Fisher Chi-square & 23.6187 & 0.9901 & NI & 139.196 & 0.0000 & $\mathrm{I}(1)$ \\
\hline
\end{tabular}

$\mathrm{NI}=$ Not integrated

The result is presented in Table 4 revealed that the majority of the criteria show that lag two is most suitable lag length for this study.

Table 4. VAR lag order selection criteria

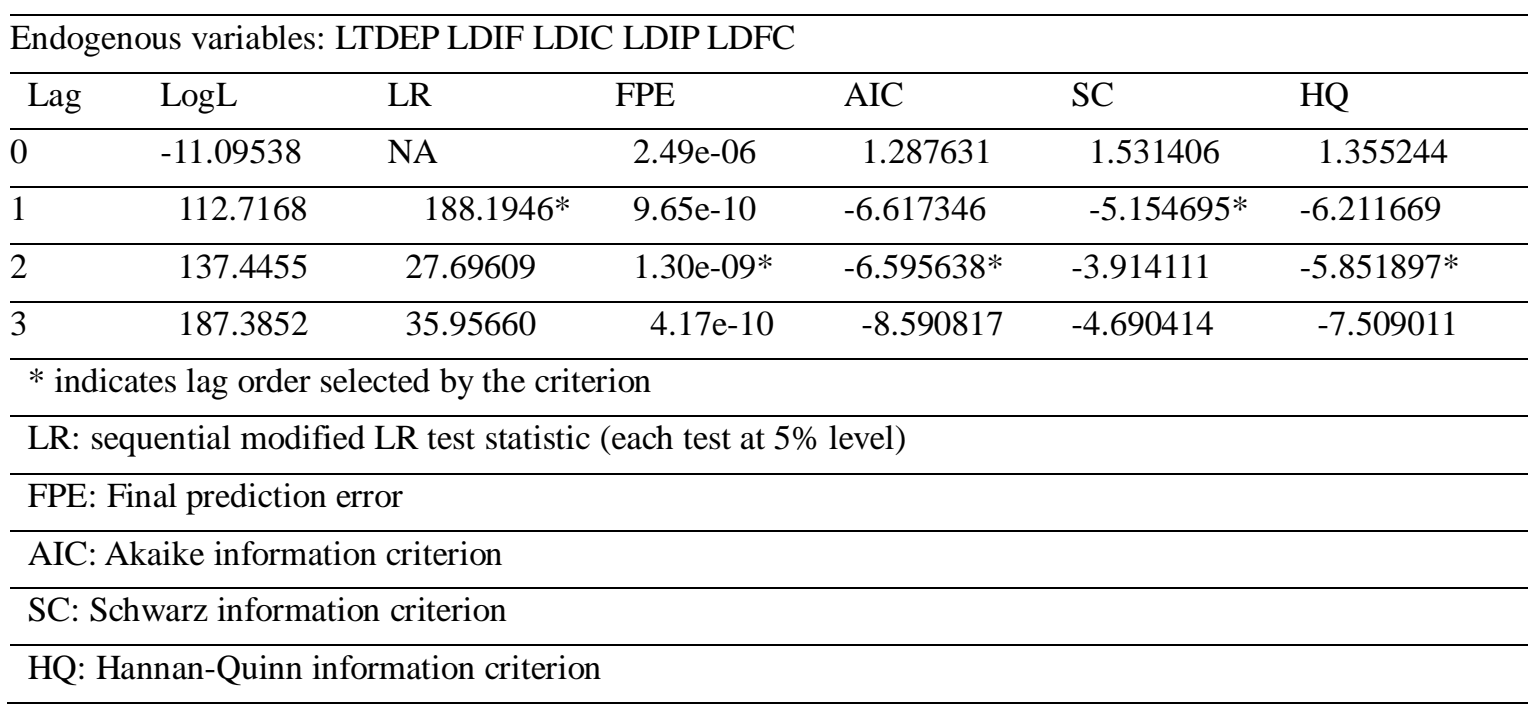

From the Pedroni test result, there are eleven test statistics. The expectation was that majority of the test statistics should have their probability of less than five per cent. In other words, the majority of the test statistics of the Pedroni co-integration test results should be significant. A review of the Pedroni result should that 6 out of the 11 test statistics were significant. This implied that there was a long-run cointegration among the variables of the model. Since the series were integrated of order I(1) and were cointegrated, the study proceeded to estimate the panel VECM. 
Table 5. Pedroni Residual cointegration test result

\begin{tabular}{lcccc}
\hline \multicolumn{4}{l}{ Alternative hypothesis: common AR coefs. (within-dimension) } \\
\hline & \multicolumn{5}{l}{ Weighted } \\
\hline Panel v-Statistic & 0.219042 & $\underline{\text { Prob. }}$ & $\underline{\text { Statistic }}$ & Prob. \\
\hline Panel rho-Statistic & 0.610686 & 0.7293 & 0.219042 & 0.4133 \\
\hline Panel PP-Statistic & -6.695270 & 0.0000 & -6.695270 & 0.0000 \\
\hline Panel ADF-Statistic & -2.237769 & 0.0126 & -2.237769 & 0.0126 \\
\hline
\end{tabular}

Alternative hypothesis: individual AR coefs. (between-dimension)

\begin{tabular}{lcl}
\hline & Statistic & Prob. \\
\hline Group rho-Statistic & 1.079384 & 0.8598 \\
\hline Group PP-Statistic & -7.911286 & 0.0000 \\
\hline Group ADF-Statistic & -2.442244 & 0.0073 \\
\hline
\end{tabular}

Table 6 present the vector error correction estimates of the parameters of the model with five equations. Equation one, however, was the equation of interest of this study. It is important to note that the values in brackets () represents the standard errors while those in the braces [ ] represents the t-statistics. Since the table 6 did not display the P-values of the t-statistics, the study generated a system equation from table 6 above for equation one. The result of the system equation is presented in Table 7.

Table 6. Vector error correction estimates result

\begin{tabular}{|c|c|c|c|c|c|}
\hline Cointegrating Eq: & CointEq1 & & & & \\
\hline LTDEP(-1) & 1.000000 & & & & \\
\hline \multirow[t]{3}{*}{ LDIF(-1) } & -1.232640 & & & & \\
\hline & $(0.47236)$ & & & & \\
\hline & {$[-2.60951]$} & & & & \\
\hline \multirow[t]{3}{*}{$\mathrm{LDIC}(-1)$} & 0.936255 & & & & \\
\hline & $(0.88710)$ & & & & \\
\hline & {$[1.05541]$} & & & & \\
\hline \multirow[t]{3}{*}{ LDIP(-1) } & 2.162818 & & & & \\
\hline & $(0.55656)$ & & & & \\
\hline & [3.88608] & & & & \\
\hline \multirow[t]{3}{*}{ LDFC(-1) } & -1.223699 & & & & \\
\hline & $(0.49322)$ & & & & \\
\hline & {$[-2.48103]$} & & & & \\
\hline $\mathrm{C}$ & -24.61422 & & & & \\
\hline Error Correction: & D(LTDEP) & $\mathrm{D}(\mathrm{LDIF})$ & $\mathrm{D}(\mathrm{LDIC})$ & $\mathrm{D}(\mathrm{LDIP})$ & $\mathrm{D}(\mathrm{LDFC})$ \\
\hline \multirow[t]{3}{*}{ CointEq1 } & 0.005816 & 0.109165 & $-8.60 \mathrm{E}-05$ & -0.051160 & 0.117997 \\
\hline & $(0.02533)$ & $(0.02574)$ & $(0.00023)$ & $(0.01214)$ & $(0.02476)$ \\
\hline & [0.22959] & [4.24028] & {$[-0.38175]$} & {$[-4.21294]$} & [4.76545] \\
\hline \multirow[t]{3}{*}{ D(LTDEP(-1)) } & -0.201988 & -0.059958 & 0.000275 & 0.010271 & -0.102826 \\
\hline & $(0.09294)$ & $(0.09446)$ & $(0.00083)$ & $(0.04455)$ & $(0.09085)$ \\
\hline & [-2.17322] & {$[-0.63477]$} & [ 0.33304$]$ & [ 0.23053$]$ & [-1.13188] \\
\hline $\mathrm{D}(\operatorname{LTDEP}(-2))$ & -0.185410 & -0.099451 & 0.000398 & 0.074340 & -0.166702 \\
\hline
\end{tabular}




\begin{tabular}{|c|c|c|c|c|c|}
\hline & $(0.09182)$ & $(0.09331)$ & $(0.00082)$ & $(0.04401)$ & $(0.08974)$ \\
\hline & {$[-2.01933]$} & {$[-1.06580]$} & {$[0.48750]$} & [ 1.68905$]$ & {$[-1.85751]$} \\
\hline \multirow[t]{3}{*}{$\mathrm{D}(\mathrm{LDIF}(-1))$} & 0.027003 & -0.140498 & -0.001951 & 0.047972 & -0.016959 \\
\hline & $(0.11398)$ & $(0.11583)$ & $(0.00101)$ & $(0.05464)$ & $(0.11141)$ \\
\hline & {$[0.23691]$} & {$[-1.21292]$} & {$[-1.92421]$} & {$[0.87801]$} & {$[-0.15222]$} \\
\hline \multirow[t]{3}{*}{$\mathrm{D}(\mathrm{LDIF}(-2))$} & 0.184277 & 0.119924 & 0.000277 & 0.012861 & 0.098957 \\
\hline & $(0.11161)$ & $(0.11342)$ & $(0.00099)$ & $(0.05350)$ & $(0.10909)$ \\
\hline & [ 1.65112] & [ 1.05732] & [ 0.27918] & [ 0.24040$]$ & [ 0.90713] \\
\hline \multirow[t]{3}{*}{$\mathrm{D}(\mathrm{LDIC}(-1))$} & -1.420558 & 0.333814 & -0.023680 & -1.017765 & -0.361185 \\
\hline & $(9.44344)$ & $(9.59705)$ & $(0.08400)$ & $(4.52677)$ & $(9.23025)$ \\
\hline & {$[-0.15043]$} & {$[0.03478]$} & {$[-0.28191]$} & {$[-0.22483]$} & {$[-0.03913]$} \\
\hline \multirow[t]{3}{*}{$\mathrm{D}(\mathrm{LDIC}(-2))$} & -1.490317 & 0.589777 & 0.774942 & -0.659215 & 0.541661 \\
\hline & $(9.23822)$ & $(9.38849)$ & $(0.08217)$ & $(4.42840)$ & $(9.02966)$ \\
\hline & {$[-0.16132]$} & {$[0.06282]$} & [ 9.43069] & {$[-0.14886]$} & {$[0.05999]$} \\
\hline \multirow[t]{3}{*}{$\mathrm{D}(\mathrm{LDIP}(-1))$} & -0.172811 & -0.118467 & -0.002349 & -0.066468 & -0.088230 \\
\hline & $(0.19588)$ & $(0.19906)$ & $(0.00174)$ & $(0.09390)$ & $(0.19146)$ \\
\hline & {$[-0.88224]$} & {$[-0.59512]$} & {$[-1.34832]$} & {$[-0.70789]$} & {$[-0.46084]$} \\
\hline \multirow[t]{3}{*}{$\mathrm{D}(\mathrm{LDIP}(-2))$} & -0.314019 & -0.235536 & -0.003267 & -0.026517 & -0.216848 \\
\hline & $(0.18865)$ & $(0.19172)$ & $(0.00168)$ & $(0.09043)$ & $(0.18439)$ \\
\hline & {$[-1.66455]$} & {$[-1.22854]$} & {$[-1.94670]$} & {$[-0.29323]$} & {$[-1.17601]$} \\
\hline \multirow[t]{3}{*}{$\mathrm{D}(\operatorname{LDFC}(-1))$} & 0.084178 & 0.079750 & 0.000665 & -0.116452 & -0.027995 \\
\hline & $(0.13182)$ & $(0.13397)$ & $(0.00117)$ & $(0.06319)$ & $(0.12885)$ \\
\hline & {$[0.63856]$} & [ 0.59529$]$ & [ 0.56743$]$ & {$[-1.84287]$} & {$[-0.21727]$} \\
\hline \multirow[t]{3}{*}{$\mathrm{D}(\operatorname{LDFC}(-2))$} & -0.187155 & -0.154608 & 0.000114 & -0.091375 & -0.077850 \\
\hline & $(0.12525)$ & $(0.12729)$ & $(0.00111)$ & $(0.06004)$ & $(0.12242)$ \\
\hline & {$[-1.49428]$} & {$[-1.21466]$} & {$[0.10237]$} & {$[-1.52194]$} & {$[-0.63592]$} \\
\hline \multirow[t]{3}{*}{$\mathrm{C}$} & 0.759837 & 1.062658 & 0.001161 & -0.059840 & 1.197297 \\
\hline & $(0.26744)$ & $(0.27179)$ & $(0.00238)$ & $(0.12820)$ & $(0.26140)$ \\
\hline & [2.84113] & [ 3.90982] & {$[0.48803]$} & {$[-0.46677]$} & [4.58026] \\
\hline R-squared & 0.535806 & 0.188473 & 0.091052 & 0.145248 & 0.218255 \\
\hline Adj. R-squared & 0.489834 & 0.122349 & 0.016990 & 0.075601 & 0.154557 \\
\hline Sum sq. resids & 932.5924 & 963.1783 & 0.073785 & 214.2933 & 890.9597 \\
\hline S.E. equation & 2.628325 & 2.671077 & 0.023378 & 1.259904 & 2.568988 \\
\hline F-statistic & 9.479927 & 2.850286 & 1.229397 & 2.085497 & 3.426413 \\
\hline Log likelihood & -344.3778 & -346.7497 & 349.7982 & -236.2871 & -341.0212 \\
\hline Akaike AIC & 4.848678 & 4.880948 & -4.595894 & 3.378055 & 4.803009 \\
\hline Schwarz SC & 5.092795 & 5.125065 & -4.351777 & 3.622172 & 5.047126 \\
\hline Mean dependent & 0.643018 & 0.914940 & 0.003475 & -0.154313 & 1.023966 \\
\hline S.D. dependent & 2.650941 & 2.851186 & 0.029929 & 1.310411 & 2.793959 \\
\hline \multicolumn{2}{|c|}{ Determinant resid covariance (dof adj.) } & 0.087330 & & & \\
\hline \multicolumn{2}{|c|}{ Determinant resid covariance } & 0.057049 & & & \\
\hline \multicolumn{2}{|c|}{ Log likelihood } & -832.4268 & & & \\
\hline \multicolumn{2}{|c|}{ Akaike information criterion } & 12.20989 & & & \\
\hline \multicolumn{2}{|c|}{ Schwarz criterion } & 13.53219 & & & \\
\hline \multicolumn{2}{|c|}{ Number of coefficients } & 65 & & & \\
\hline
\end{tabular}


From the result, $\mathrm{C}(1)$ was the error correction term that measured the speed of adjustment of the total deposit towards long-run equilibrium. The expectation about $\mathrm{C}(1)$ was that it must be negative and significant at 5 per cent level. From the result above, $\mathrm{C}(1)$ was neither negative nor significant at 5 per cent level. This meant therefore that there was no long-run causality from deposit insurance fund, deposit insurance cover, deposit insurance premium, and deposit fully covered to total deposit; meaning that IADI's member countries deposit insurance schemes had not significantly influenced deposit mobilization by insured banks in member countries in the long run. In other words, there was no long-run causality running from deposit insurance schemes to deposit mobilization in IADI's member countries. The analysis of the signs of the short-run parameter of the model revealed that there was a positive effect of deposit insurance fund on total deposit of IADI's member countries both in the first and second lagged periods. The implication of this was that a percentage increase in deposit insurance funds resulted in a corresponding increase in banks' deposit mobilization in IADI's member countries, ceteris paribus. The result also showed that there was a negative effect of deposit insurance cover on banks' deposit mobilization in IADI's member countries both in the first and second lagged periods. The implications of the negative effect were that, a percentage increased in deposit insurance cover led to a reduction in banks' deposit mobilization both in the first and second lagged periods, ceteris paribus.

The result further showed that there was a negative effect of deposit insurance premium on total deposits both at first and second lagged periods. This implied that a one per cent increase in deposit insurance premium led respectively to 17.28 per cent and 31.40 per cent decreases in total deposit mobilization of IADI's member countries, ceteris paribus. Lastly, the result further showed that, in the first lagged period, deposit fully covered had a positive effect on total deposit mobilization of IADI's member countries; however, in the second lagged period, deposit fully covered had a negative effect on the total deposit mobilization of IADI's member countries. The implication of this was that sustained increases in the fully coverage level of deposit money banks reduced the level of deposit mobilization of IADI's member countries, ceteris paribus. Furthermore, the $\mathrm{R}^{2}$ value 0.5358 or 53.58 per cent showed that about 53.58 per cent of the observed changes in bank deposit of IADI's member countries had been explained by the variations in deposit insurance scheme such as deposit insurance fund, deposit insurance cover, depositor insurance premium and deposit fully covered. The F-statistics value of 2.15 with it corresponding probability of 5.13 per cent showed that the total deposit equation model was not statistically significant at 5 per cent level.

Table 7. Vector error correction system estimates result

\begin{tabular}{lllll}
\hline & Coefficient & Std. Error & t-Statistic & Prob. \\
\hline $\mathrm{C}(1)$ & 0.005816 & 0.025333 & 0.229594 & 0.8185 \\
\hline $\mathrm{C}(2)$ & -0.201988 & 0.092944 & -2.173223 & 0.0301 \\
\hline $\mathrm{C}(3)$ & -0.185410 & 0.091817 & -2.019331 & 0.0438 \\
\hline $\mathrm{C}(4)$ & 0.027003 & 0.113980 & 0.236905 & 0.8128 \\
\hline $\mathrm{C}(5)$ & 0.184277 & 0.111607 & 1.651121 & 0.0992 \\
\hline $\mathrm{C}(6)$ & -1.420558 & 9.443439 & -0.150428 & 0.8805 \\
\hline $\mathrm{C}(7)$ & -1.490317 & 9.238219 & -0.161321 & 0.8719 \\
\hline $\mathrm{C}(8)$ & -0.172811 & 0.195878 & -0.882236 & 0.3780 \\
\hline $\mathrm{C}(9)$ & -0.314019 & 0.188651 & -1.664545 & 0.0965 \\
\hline $\mathrm{C}(10)$ & 0.084178 & 0.131824 & 0.638564 & 0.5233 \\
\hline $\mathrm{C}(11)$ & -0.187155 & 0.125248 & -1.494280 & 0.1356 \\
\hline $\mathrm{C}(12)$ & 0.759837 & 0.267441 & 2.841132 & 0.0046 \\
\hline $\mathrm{R}$-squared & 0.535806 & & & \\
\hline Adjusted R-squared & 0.489834 & & & \\
\hline F-Statistics & 2.154326 & Durbin Watson stat & 2.309076 \\
\hline Prob(F-statistic) & 0.051354 & & & \\
\hline
\end{tabular}


Table 8 showed that all the null hypotheses of this study were rejected, meaning that there was no short-run causality running from the deposit insurance fund, deposit insurance cover, deposit insurance premium and deposit fully covered on banks' deposit mobilization in IADI's member countries. In other words, deposit insurance scheme efforts of IADI's member countries did not significantly affect deposit mobilization of banks within the period under review.

Table 8. Short joint significance using Wald test

\begin{tabular}{lllll}
\hline \multicolumn{2}{l}{ Dependent variable: LTDEP } & & & \\
\hline Variable & Null hypotheses & Chi-square value & Prob - value & Decision \\
\hline LDIF & $\mathrm{C}(4)=\mathrm{C}(5)=0$ & 2.727199 & 0.2557 & Rejected \\
\hline LDIC & $\mathrm{C}(6)=\mathrm{C}(7)=0$ & 0.047887 & 0.9763 & Rejected \\
\hline LDIP & $\mathrm{C}(8)=\mathrm{C}(9)=0$ & 3.209644 & 0.2009 & Rejected \\
\hline LDFC & $\mathrm{C}(10)=\mathrm{C}(11)=0$ & 3.362743 & 0.1861 & Rejected \\
\hline
\end{tabular}

\section{Conclusion}

The analyses revealed that deposit insurance fund, deposit insurance cover, deposit insurance premium and deposit fully covered jointly did not cause deposit mobilization of banks in IADI's member countries in the long run. This implied that the gains of the IADI's policies and core principles were yet to be enjoyed by member countries in terms of building confidence among member countries' banking sectors, indicative by reduced deposit mobilization. IADI, as a policy-making body must, therefore, review and localize its core principles and policies in line with member countries' uniqueness and financial realities through investment in research in member countries to isolate unique factors peculiar to member countries and streamline policies to capture member countries' financial and economic conditions.

Also, the study showed that the short-run deposit insurance fund had a positive but insignificant effect on member country's deposit mobilization. This implied that an increase in short-run deposit insurance fund triggered growth in IADI's member countries' deposit mobilization. This, therefore, calls on IADI's member countries deposit insurance agencies to enhance the scope of its deposit insurance fund enhancing their current deposit insurance fund yielding windows to sustain the growth level in deposits. The analyses further revealed that the deposit insurance scheme in terms of deposit insurance cover and deposit insurance premium had a negative and insignificant effect on deposit mobilization of IADI's member countries' banking sector. This meant that deposit insurance premium and cover had debilitating effects on member countries deposit mobilization capacity. In other words, deposit insurance premium and cover in the short run did not trigger growth in deposit mobilization of IADI's member countries. IADI's must monitor the compliance level of member countries to ensure strict implementation of its policy and principles bordering on premium and insurance cover.

Lastly, the study showed that the initial increase in deposit fully covered of member countries enhanced the deposit mobilization capacity of the banking sectors of IADI's member countries in the short run. However, sustained increases in short-run deposit fully covered retarded growth in member countries' banking sectors deposit mobilization. Member country's deposit insurance agencies must align with IADI's core principles to ensure that all deposits of banks are fully covered to sustain an enhance effect of fully covered deposits on member countries' deposit mobilization.

\section{References}

Akogun, P. (2010). Sanusi's reforms angels to the rescue? Retrieved from: http://allafrica.com/stories/20100 2/700

Andreas, H., Larysa, S., \& Sergii, B. (2018). Deposit insurance systems of post-Soviet countries: A comparative analysis. Journal of International Studies, 11(4), 22-44. https://doi.org/10.14254/2071- 8330.2018/11-4/2

Anginer, D., \& Demirguc-Kunt, A. (2018). Bank runs and moral hazard: A review of deposit insurance. World Bank Group Policy Research Working Paper 8589.

Angkinand, A., \& Wihlborg, C. (2010). Deposit insurance coverage, ownership, and banks' risk taking in emerging markets. Journal of International Money and Finance, 29(2), 252-274. 
Ani, U. W., \& Ogar, A. (2018). Effect of deposit insurance fund on the safety of bank deposits in Nigeria. IIARD International Journal of Banking and Finance Research, 4(2), 65-73.

Beat, B., \& Susanna, W. (2009). Design, structure and implementation of a modern deposit insurance scheme. The European Money and Finance Forum, SUERF Studies, 2009/5.

Demirgüç-Kunt, A., \& Edward, J. K. (2002). Deposit insurance around the globe: Where does it work?. Journal of Economic Perspectives, 16(2), 175-195. https://doi.org/10.1257/0895330027319

Diamond, D. W., \& Dybvig, P. H. (1983). Bank runs, deposit insurance, and liquidity. Journal of Political Economics, 91(3), 401-419.

Ebiaghan, O. F. (2019). The deposit insurance scheme and moral hazard hypothesis: Nigeria evidence. Economic Horizons, 21(3), 215-227. https://doi.org/10.5937/ekonhor1903215F

Enkhbold, E., \& Otgonshar, B. (2013). The effect of deposit insurance on risk-taking in Asian banks. Asian Journal of Finance and Accounting, 5(1), 104-126. https://doi.org/10.5296/ajfa.v5i1.3023

Falko, F., Stefan, T., \& Patrick, W. (2019). Fear, deposit insurance schemes, and deposit reallocation in the German banking system. Deutsche Bundesbank Discussion Paper No. 12/2019. Retrieved from https://ssrn.com/abstract=3391551

Girma, J. D., \& Jiqin, H. (2018). Effect of deposit mobilization on the financial sustainability of rural saving and credit cooperatives: Evidence from Ethiopia. Sustainability, 10(10), 1-23. https://doi.org/10.3390/su10103387

Honohan, P., \& Klingebiel, D. (2000). Controlling the fiscal costs of banking crises. World Bank Policy Research Working Paper No. 2441, Retrieved from https://ssrn.com/abstract=282514

Jan P. N., \& Isfandyar, Z. K. (2017). Deposit insurance systems: Addressing emerging challenges in funding investments, risk-based contributions and stress testing. World Bank Group Financial Sector Advisory Centre. Retrieved from www.worldbank.org/finsac

Karabulut, S. E. L., \& Bilgin, P. O. (2007). Bank failures: The deposit insurance connection contemporary policy issues. Central Bank of Nigeria Economic and Financial Review, 29(2), 200-241.

Ngalawa, H., Tchana, F., \& Viegi, N. (2016). Banking instability and deposit insurance: The role of moral hazard. Journal of Applied Economics, 19(2), 323-350. https://doi.org/10.1016/S1514-0326(16)30013-7

Olukotun, G. A., James, O. O., \& Olorunfemi, K. (2013). Bank distress in Nigeria and the Nigeria Deposit Insurance Corporation Intervention. Global Journal of Management and Business Research Finance, 13(8), 1-11.

Peia, O., \& Vranceanu, R. (2017). Experimental evidence on bank runs under partial deposit insurance. École Supérieure Des Sciences Économiques Et Commerciales (ESSEC), Working Paper 1705. https://doi.org/10.2139/ssrn.2955171

Pham, T. C., \& Dao, T. B. (2020). Deposit insurance and bank risks in Vietnam. Business and Economic Research, 10(2), 46-63.

Piotr, D., Chun, H. L., \& Klaus, S. (2019). Private deposit insurance, deposit flows, and bank lending. Retrieved from

https://www.iadi.org/en/assets/File/Special_Workspace/2019_Research_Conference/PAPER\%204\%20-\%20Sch aeck\%20et\%20al.pdf

Sabastine, S. (2009). Financial crisis: Deposit insurance and related financial safety net aspects. OECD Journal of Financial Market Trends, 2, 73-111. https://doi.org/10.1787/fmt-v2008-art12-en

\section{Copyrights}

Copyright for this article is retained by the author(s), with first publication rights granted to the journal.

This is an open-access article distributed under the terms and conditions of the Creative Commons Attribution license (http://creativecommons.org/licenses/by/4.0/). 